DOI: https://doi.org/10.24127/ajpm.v9i3.2943

\title{
MEDIA TUTORIAL MATLAB BERBASIS WEB DALAM METODE NUMERIK SEBAGAI PENGUATAN LITERASI DIGITAL
}

\author{
Reza Kusuma Setyansah $^{1 *}$, Restu Lusiana ${ }^{2}$ \\ ${ }^{1 *}, 2$ Pendidikan Matematika, Universitas PGRI Madiun, Madiun, Indonesia \\ * Corresponding author. Universitas PGRI Madiun Jl. Setiabudi No. 85 Madiun, 63118, Madiun, Indonesia \\ E-mail: $\quad$ reza.mathedu@unipma.ac.id ${ }^{\left.1^{*}\right)}$ \\ restu.mathedu@unipma.ac.id $^{2)}$
}

Received 16 July 2020; Received in revised form 07 September 2020; Accepted 22 September 2020

\begin{abstract}
Abstrak
Penelitian ini bertujuan untuk mengetahui validitas, kepraktisan, dan efektivitas media tutorial matlab berbasis web pada materi perkuliahan metode numerik sebagai penguatan literasi digital. Untuk mencapai tujuan itu digunakan model Plomp yang terdiri dari empat tahapan yaitu: fase investigasi awal, fase desain, fase realisasi/konstruksi, fase test, evaluasi dan revisi. Subjek dalam penelitian ini adalah mahasiswa semester 4 di Universitas PGRI Madiun semester keempat tahun ajaran 2019/2020. Subjek penelitian dibagi menjadi 2 jenis yaitu, subjek uji coba terbatas dan subjek uji coba lapangan. Instrumen penelitian adalah lembar validasi media tutorial matlab, angket respon mahasiswa, dan tes prestasi belajar. Hasil penelitian ini adalah (1) media pembelajaran yang dikembangkan yang memenuhi kriteria validitas $82,00 \%$. (2) Media pembelajaran yang dikembangkan memenuhi aspek praktis $82,22 \%$ dan untuk uji coba lapangan 82,50\% (3), Media pembelajaran dikembangkan untuk memenuhi kriteria efektivitas dalam uji coba terbatas $83,33 \%$ dan uji coba lapangan $87,50 \%$. Berdasarkan hasil penelitian dapat disimpulkan bahwa media tutorial yang dikembangkan layak dan sesuai untuk digunakan sebagai penguatan literasi digital. Kondisi pencapaian penguatan literasi digital dengan menggunakan media tutorial matlab berbasis web sebesar 70,83\% terkategorikan cukup dominan terhadap aspek (1) penggunaan teknologi, (2) penggunaan smartphone dan (5) Online Safety.
\end{abstract}

Kata kunci: Literasi digital; matlab; metode numeric; tutorial; web.

\begin{abstract}
This study aims to determine the validity, practicality, and effectiveness of web-based matlab tutorial media on numerical method lecture materials as strengthening digital literacy. To achieve this goal, the Plomp model is used which consists of four stages, namely: the initial investigation phase, the design phase, the realization / construction phase, the test phase, evaluation and revision. The subjects in this study were 4th semester students at PGRI Madiun University in the fourth semester of the 2019/2020 school year. Research subjects are divided into 2 types, namely, limited trial subjects and field trial subjects. The research instruments were the validation sheet of the matlab tutorial media, student response questionnaires, and learning achievement tests. The results of this study are (1) developed learning media that meet the validity criteria of $82.00 \%$. (2) The learning media developed fulfills the practical aspects of $82.22 \%$ and for field trials $82.50 \%$ (3), the learning media is developed to meet the effectiveness criteria in limited trials $83.33 \%$ and field trials $87.50 \%$. Based on the research results, it can be concluded that the tutorial media developed are feasible and suitable for use as digital literacy strengthening. The condition for achieving digital literacy strengthening using web-based matlab tutorial media is $70.83 \%$ categorized as quite dominant in aspects (1) use of technology, (2) use of smartphones and (5) Online Safety.
\end{abstract}

Keywords: Digital literacy; matlab; numerical methods; tutorial; web. 
DOI: https://doi.org/10.24127/ajpm.v9i3.2943

\section{PENDAHULUAN}

Perkembangan teknologi melaju dengan pesat dan semakin terdorong dengan paksa akibat dampak dari pengaruh pandemi COVID-19. Pandemi covid-19 telah merubah paradigma pembelajaran langsung ke pembelajaran dengan sistem online (Reyna, 2020). Adapun pengaruh dari pandemi memaksa mahasiswa dan dosen mengadaptasi kebutuhan dalam proses belajar pembelajaran dalam perkembangan teknologi. Mahasiswa merupakan bagian dari sumber daya manusia yang harus menghadapi tantangan globalisasi. Salah satu upaya untuk mengatasi tantangan yang akan datang adalah melalui pendidikan literasi digital (Rahmah, 2015). Dalam dunia pendidikan, mahasiswa harus menyesuaikan kebutuhan dari generasi digital native. Generasi dimaksudkan merupakan budaya baru dengan perkembangan yang terlahir dari penetrasi teknologi digital yang agresif dan pesatnya perkembangan teknologi sehingga mempengaruhi kebiasaan perilaku belajar mereka dan akibatnya generasi memiliki cara berpikir dan belajar yang unik (Muchsini \& Siswandari, 2018). Perkembangan teknologi dan literasi digital secara subtansial dapat membantu seseorang mencapai tujuan (FernandezVillavicencio, 2010). Adapun capaian yang diinginkan dalam perkembangan dunia pendidikan merupakan hasil tanggapan inovasi. Melihat dari hasil penelitian (Muchsini \& Siswandari, 2020) bahwa generasi digital native akan merasa tertekan dan bosan, jika proses pembelajarannya monoton dengan generasi sebelumnya.

Pembelajaran secara daring telah telah menjadi suatu keharusan saat ini di Universitas PGRI Madiun. Pada kondisi awal dimana terjadi perkuliahan dalam bentuk blended learning, (Wardani et al., 2018) merupakan model pembelajaran yang mengkombinasi keunggulan yang dimiliki model pembelajaran tatap muka (face-to-face) dengan model pembelajaran e-learning. Pada blended learning interaksi dan komunikasi merupakan daya tarik dalam pembelajaran di era 21. Namun, karena terjadi suatu keadaan pandemi covid-19 perkuliahan dilaksanakan secara daring secara penuh. Dalam hal ini dosen yang menjalankan pesan sebagai fasilitator dituntut memiliki perspektif berbasis keterampilan pada pengembangan literasi digital (List, 2019). Dengan sistem pembelajaran berbasis digital, misalkan melalui web, mahasiswa mampu mengeksplorasi lebih banyak dan mempelajari informasi, lebih banyak sumber belajar dan peluang lebih besar untuk kolaborasi (Means et al., 2009).

Berbeda dengan pembelajaran klasik di mana pembelajaran dilakukan pada waktu dan tempat yang sama, pembelajaran atau pembelajaran online dengan memanfaatkan waktu dan tempat belajar di situs web bukanlah halangan (Broadbent \& Poon, 2015; Ku \& Chang, 2011). Adapun pelaksanaan perkuliahan secara daring melalui eLMA (e-Learning UNIPMA) yang difasilitasi oleh kampus. Pembelajaran daring memiliki kelebihan jika dibandingkan dengan pembelajaran klasik. Hal ini didukung bahwa pembelajaran berbasis web berdampak lebih fleksibilitas dan aksesibilitas bagi mahasiswa mengenai jadwal dan lokasi pembelajaran karena sulitnya pembelajaran diadakan secara tatap muka di kelas (Waschull, 2001).

Pembelajaran secara daring akan menjadi sangat monoton apabila hanya diberikan melalui tampilan teks kepada mahasiswa melalui laman web. Melihat 
dari penelitian terdahulu bahwa dalam penelitian (Setyansah \& Apriandi, 2019) buku teks yang akan dikembangkan dilengkapi dengan simulasi video tentang cara melakukan perhitungan menggunakan Matlab, mampu meningkatkan kemandirian belajar. Pembaharuan dalam penelitian ini lebih menekankan konten tutorial dengan penguatan literasi digital, yang disematkan ke dalam e-learning (eLMA) sehingga terjadi interaksi dalam proses pembelajaran secara daring. Capaian utama yang penting dalam pembelajaran daring memerlukan adanya penguatan literasi digital, (Atep \& Dewi, 2019) tidak hanya sekedar menambahkan teknologi ke dalam proses pembelajaran, akan tetapi manfaatkan untuk berbagai kepentingan dalam rangka meningkatkan mutu pembelajaran tersebut. (Sari et al., 2019) Menjadi individu berliterasi digital adalah mampu memahami penggunaan teknologi digital terkait pengelolaan informasi untuk menciptakan pengetahuan dan inovasi baru. Masalah yang muncul dari penelitian terdahulu, masih dalam disisipkan dalam textbook sehingga belum ada penguatan literasi digital di dalam tutorial yang dikemas ke dalam bentuk web ataupun e-Learning. Harapan yang dicapai dalam media tutorial ini mahasiswa mampu mengakses media tutorial di eLMA sehingga melakukan inovasi dan kemandirian dalam perhitungan dengan menggunakan program matlab.

Dari uraian latar belakang, maka masalah dalam penelitian ini adalah sebagai berikut: (1) Bagaimana prosedur pengembangan media tutorial matlab berbasis web pada mata kuliah metode numerik? (2) Apakah media tutorial matlab, layak dipergunakan penguatan literasi digital mahasiswa?
Tujuan yang ingin dicapai dalam penelitian ini adalah tercipta media tutorial matlab berbasis web dalam metode numerik sebagai penguatan literasi digital.

\section{METODE PENELITIAN}

Penelitian ini merupakan penelitian pengembangan (R\&D), dengan menggunakan model Plomp (1997). Adapun dalam model penelitian ini dengan menerapkan lima tahapan yaitu: fase investigasi awal, fase desain, fase realisasi/konstruksi, fase test, evaluasi dan revisi, dan fase implementasi (Hobri, 2010). Pembatasan pada fase kelima tidak diikutsertakan karena memerlukan tingkat lanjut implementasi dan evaluasi yang mendalam, maka diharapkan menjadi penelitian lanjutan. Fase yang yang dilaksanakan dalam penelitian ini dibatasi hingga fase keempat dapat dilihat pada Gambar 1.

Subjek ujicoba dalam penelitian ini adalah sejumlah mahasiswa kelas IVB program studi mahasiswa teknik informatika sebanyak 22 mahasiswa pada perkuliahan kelas metode numerik.

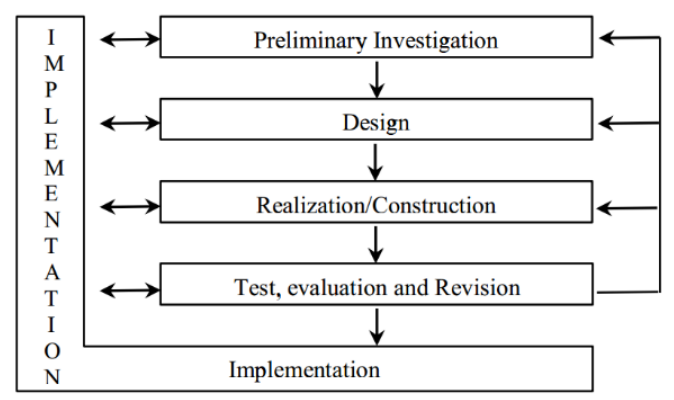

Gambar 1. Model Alur Plomp

Instrumen yang dipergunakan dalam penelitian ini dibuat dalam bentuk google form untuk mempermudah pengambilan data di masa pandemic ini. Adapun instrumen yang dipergunakan dalam penelitian ini adalah lembar validasi ahli (ahli media 
DOI: https://doi.org/10.24127/ajpm.v9i3.2943

dan ahli materi), angket respon mahasiswa, tes prestasi belajar.

Validitas dari produk yang dikembangkan didasarkan pada hasil dari lembar angket validitas materi maupun media. Dalam penelitian pengembangan media tutorial matlab berbasis web ini melibatkan dua pakar sebagai validator. Adapun penilaian mengacu tiga penilaian validasi produk yaitu konten, tampilan dan bahasa. Untuk mengetahui persentase keseluruhan, (Akbar, 2013) dapat dicari dengan rumus rata-rata sebagai berikut:

$$
\mathrm{V}=\frac{\mathrm{V}_{1}+\mathrm{V}_{2}+\cdots+\mathrm{V}_{\mathrm{n}}}{\mathrm{n}}=\cdots \%
$$

Media pembelajaran berbasis web dinyatakan valid (baik/cukup baik) jika hasil validitas gabungannya menunjukkan hasil lebih dari $70 \%$.

$$
\mathrm{V}=\frac{\text { Total Skor Empiris }}{\text { Total Skor Harapan }} \times 100 \%
$$

Analisis kepratisan dari produk didasarkan dari data hasil kuesioner respon mahasiswa. Data yang diperoleh kemudian dianalisis untuk menentukan tingkat kepraktisan media pembelajaran. Kuesioner respon mahasiswa disusun menggunakan skala Likert dengan metode daftar periksa. Media tutorial dapat memenuhi kriteria kepraktisan media jika memberikan kriteria $\geq 70 \%$ mahasiswa secara klasik memberikan respon positif (Saputro, 2011). Jika kurang dari $70 \%$ maka harus melakukan perbaikan pada media pembelajaran berdasarkan saran yang diberikan oleh mahasiswa.

Analisis efektivitas, dalam penggunaan media tutorial dapat dikatakan efektif jika $80 \%$ mahasiswa memenuhi penguasaan pembelajaran. Hal ini terlihat dari hasil tes yang diberikan kepada mahasiswa dan dinyatakan selesai dengan penguasaan baik. (Hobri, 2010) apabila persentase kelengkapan individu dinayatakan baik atau terpenuhi telah mencapai $\geq 80 \%$ yang secara klasik memperoleh skor minimum 75 dari skor keseluruhan.

Analisis penguatan literasi digital, diidentifikasi berdasarkan dari instrumen penelitian (Febliza \& Oktariani, 2020), berdasarkan kisi-kisi mengadaptasi dari angket literasi digital mahasiswa yang mengacu secara umum dari 6 indikator dengan total 30 butir pertanyaan. Adapun dalam rincian memperoleh hasil angket literasi digital mahasiswa dapat dilihat dari Tabel 1 .

Tabel 1. Indikator Literasi Digital

\begin{tabular}{clcc}
\hline Aspek & \multicolumn{1}{c}{ Indikator } & Butir Pertanyaan & Jumlah \\
\hline (1) & Penggunaan Teknologi & $1,2,3,4,5,6$ & 6 \\
$(2)$ & Penggunaan & $7,8,9,10,11,12,13,14$, & 12 \\
& Smartphone/Handphone & $15,16,17,18$ \\
(3) & Jejaring Sosial & $19,20,21,22$ & \\
$(4)$ & Pengaturan Privacy & $23,24,25,26$ & 4 \\
$(5)$ & Online Safety & 27,28 & 2 \\
& Dampak Positif Teknologi & 29,30 & 2 \\
\hline \multicolumn{2}{r}{ Total } & $\mathbf{3 0}$ \\
\hline
\end{tabular}

Sumber : (Febliza \& Oktariani, 2020)

\section{HASIL DAN PEMBAHASAN}

Adapun pelaksanaan penelitian ini, dilaksanakan dengan susunan tahapan model Plomp (Hobri, 2010), yaitu fase investigasi awal, fase desain, fase realisasi/konstruksi dan fase tes, evaluasi dan revisi. Pemaparan pada 
DOI: https://doi.org/10.24127/ajpm.v9i3.2943

setiap hasil pelaksanaan dalam penelitian sebagai berikut:

A. Fase Investigasi Awal

Dalam tahapan ini dilaksanakan penelusuran dalam masalah yang didefinisikan, dengan melihat dari kesenjangan antara kondisi ideal yang dicapai dan fakta yang terjadi dilapangan. Ada beberapa masalah dalam penelusuran awal ini diperoleh, sehingga dilakukan perubahan dalam pembuatan media tutorial. Masalahmasalah itu diantaranya sebagai berikut.

1. Kondisi yang awalnya terlaksana dalam keadaan perkuliahan secara blended learning teralihkan menjadi menjadi pembelajaran daring sepenuhnya. Hal ini yang menjadikan kegagapan bagi mahasiswa untuk menyesuaikan kondisi tersebut. Hal serupa juga dirasakan oleh beberapa pengajar/ dosen dalam menyampaikan materi/ tatap muka secara daring, sehingga membutuhkan adaptasi dalam menyampaikan materi.

2. Pembelajaran daring penuh yang dilaksanakan melalui pihak ketiga (platform zoom) terdapat beberapa mahasiswa yang tidak mampu mengikuti perkuliahan secara serentak atau diantara terjadi ketertinggalan materi karena berbagai kendala teknis jaringan internet.

3. Kondisi ketertinggalan materi, mengakibatkan pengajar atau dosen menyampaikan ulang materi yang telah disampaikan pada saat perkuliahan daring.

\section{B. Fase Desain}

Dalam tahapan fase desain adalah bentuk dari cetak biru yang merupakan solusi dari investigasi awal, oleh karena itu ketelitian dalam menyusun desain sangat dibutuhkan. Diantaranya masalah yang umum digambarkan pada tahapan fase pertama yang harus dibatasi dan diarahkan ke fokus penelitian sehingga tidak terlalu meluas. Adapun desain yang diberikan, mengacu pada kondisi ketertinggalan materi yang mana dalam kegiatan perkuliahan daring, pengajar tidak mengulangi kembali materi yang telah disampaikan. Adapun penyusunan desain yang dipersiapkan sebagai berikut.

1. Software snapgit tool dan hypercam, yang dipergunakan untuk merekam tampilan desktop dalam menyampaikan langkah dari setiap perhitungan pada materi perkuliahan metode numerik.

2. Software filmora, yang dipergunakan sebagai penyuntingan hasil rekaman yang akan disusun menjadi tampilan materi.

3. Platform youtube studio, yang dipergunakan sebagai tampilan dari keseluruhan materi yang sudah dipersiapan baik materi secara tertulis atau petunjuk teknis perhitungan metode numerik.

4. Penyematan hasil tutorial materi kedalam materi di e-learning UNIPMA (ELMA)

5. Instrumen angket validasi ahli materi dan ahli media.

6. Instrumen angket respon mahasiswa.

7. Instrumen angket mahasiswa.

C. Fase Konstruksi

Dalam proses konstruksi dilaksanakan tahapan pertama dengan pembuatan screen record tampilan desktop yang menggunakan software snapgit tool dan hypercam serta penghitungan metode numerik dengan matlab. Hal ini dapat dilihat hasil image capture dari screen record penggunaan perhitungan dengan menggunakan matlab pada Gambar 2. 
DOI: https://doi.org/10.24127/ajpm.v9i3.2943

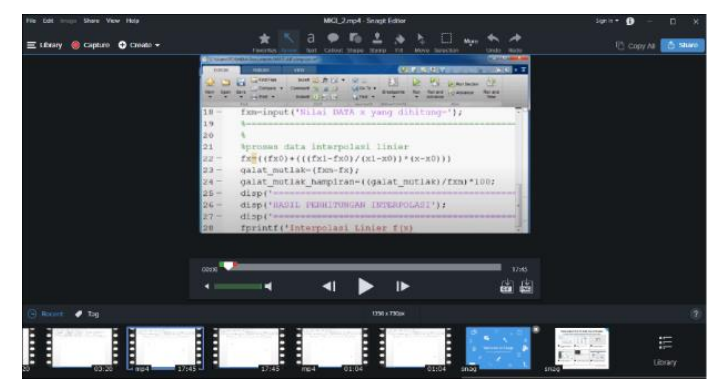

Gambar 2. Screen Record (Snapgit)

Pada proses tahapan kedua yaitu dengan melakukan penyutingan hasil screen record menggunakan software filmora dan dilakukan penyisipan sound dan petunjuk pemakaian dengan text. Hal ini dapat dilihat hasil image capture dari penggunaan penyutingan video dengan menambahkan text dan suara petunjuk penggunaan pada Gambar 3 .

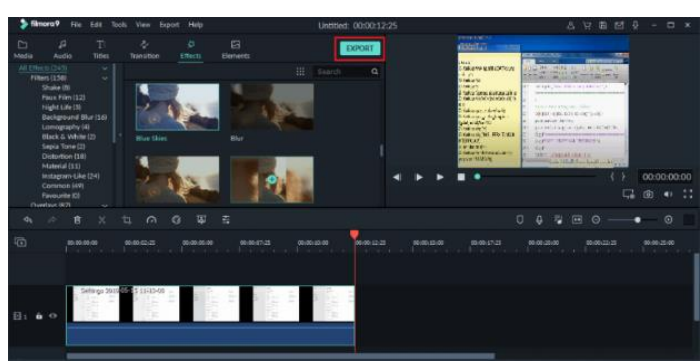

Gambar 3. Penyuntingan video

(Filmora)

Pada proses tahapan ketiga, dimana hasil dari yang telah dilakukan penyuntingan teks dan suara diunggah dan diurutkan sesuai penyajian dalam setiap materinya di youtube studio. Adapun hasil yang telah diunggah akan disematkan ke eLMA (e-learning UNIPMA) seperti yang tertera pada Gambar 4.

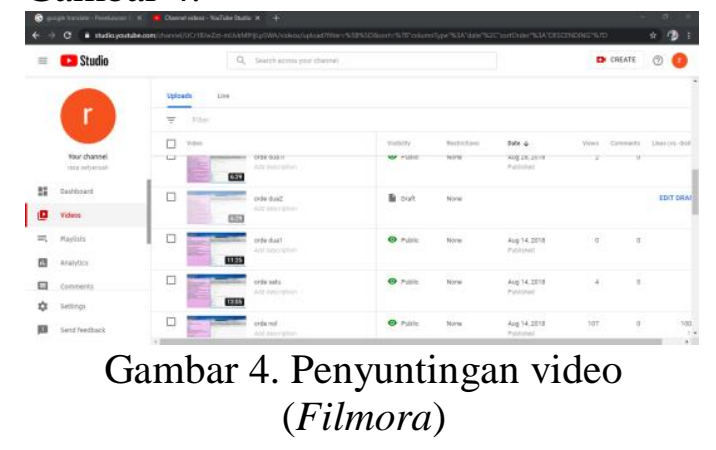

Pada proses tahapan keempat ini, merupakan tahapan akhir dalam proses kontruksi yang mana hasil yang telah diproses disematkan ke ELMA (elearning UNIPMA) pada Gambar 5.

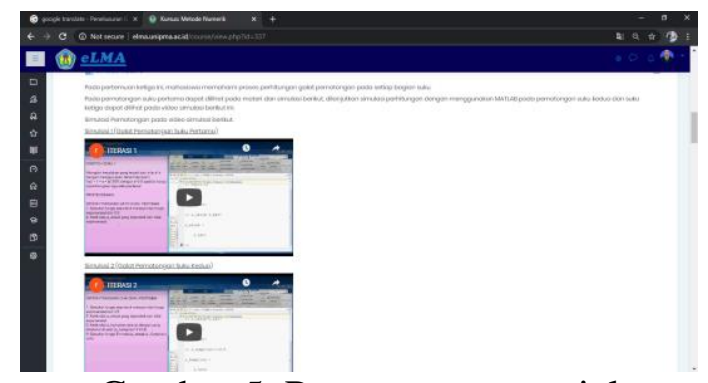

Gambar 5. Penyematan tutorial

D. Fase Evaluasi, Test dan Revisi

Pada fase ini, produk hasil pengembangan tahapan I diberikan nama prototipe I dan produk hasil revisi disebut prototipe II, prototipe III dan seterusnya.

Adapun hasil arahan perbaikan dari para ahli/pakar disajikan dalam bentuk deskripsi beberapa revisi sebagai berikut.

1. Tampilan desain awal web tutorial disematkan melalui wordpress yang menurut ahli media bahwa laman yang dipergunakan terlalu banyak panel tampilan dan membingungkan. Oleh karena itu, dianjurkan oleh oleh ahli media untuk digantikan ke google sites, setelah diujikan menjadi lebih sederhana memuat konten dan gampang dipergunakan.

2. Terdapat beberapa kesalahan pengetikan notasi matematika yang tidak tampil dan perlu diperbaiki menurut ahli materi.

3. Tampilan tidak disertai petunjuk suara, maka dianjurkan oleh ahli media dan ahli materi untuk menambahkan petunjuk suara.

Hasil dari perbaikan disesuaikan dengan hasil dari validasi ahli/pakar 
DOI: https://doi.org/10.24127/ajpm.v9i3.2943

yang diperoleh dari lembar validasi uji kelayakan media tutorial matlab. hasil uji validitas meliputi validitas konten, tampilan, dan bahasa. Hasil dari uji validitas media tutorial matlab dapat dilihat pada Tabel 2.

Tabel 2. Hasil Uji Kelayakan berdasarkan Lembar Validasi Media

\begin{tabular}{ccccc}
\hline Validator & Konten & Tampilan & Bahasa & $\begin{array}{c}\text { Skor } \\
\text { Rata-rata }\end{array}$ \\
\hline I & 4,48 & 4,40 & 4,57 & 4,48 \\
II & 4,42 & 4,39 & 4,56 & 4,46 \\
\hline
\end{tabular}

Berdasarkan Tabel 2 menunjukkan hasil uji kelayakan lembar validasi media tutorial matlab oleh kedua validator dan didapatkan skor rata-rata masing-masing 4,48 dan 4,46. Dan dari kumulasi kedua validator didapatkan rata-rata 4,47 .
Hasil yang diperoleh dari validasi tanggapan kuesioner mahasiswa, maka mengenai media tutorial matlab berbasis web memperoleh validasi respon kuesioner mahasiswa dapat dilihat pada Tabel 3.

Tabel 3. Hasil Validasi Respon Kuesioner Mahasiswa (Media)

\begin{tabular}{cccccc}
\hline \multirow{2}{*}{ Validator } & \multicolumn{4}{c}{ Skor Aspek } & \multirow{2}{*}{$\begin{array}{c}\text { Skor Rata- } \\
\text { rata }\end{array}$} \\
\cline { 2 - 5 } & Bahasa & Kesesuaian & Kejelasan & Kelayakan & $\mathbf{4 , 6 0}$ \\
I & $\mathbf{4 , 6 7}$ & $\mathbf{4 , 6 5}$ & $\mathbf{4 , 8 5}$ & $\mathbf{4 , 2 2}$ & $\mathbf{4 , 6 4}$ \\
\hline
\end{tabular}

Berdasarkan Tabel 3, hasil validasi angket respons mahasiswa diperoleh skor rata-rata masing-masing validator berdasarkan empat komponen yaitu bahasan kesesuaian, kejelasan dan kelayakan memperoleh 4,60 dan 4,64 dari dua validator 4,62 skala 5 .

Setelah diperoleh hasil pengujian dilanjutkan untuk menguji kepraktisan produk. Hasil yang diperoleh dari validasi tanggapan kuesioner mahasiswa mengenai literasi digital dapat dilihat pada Tabel 4.

Berdasarkan tabel 4, hasil validasi angket literasi digital mahasiswa diperoleh skor rata-rata masing-masing validator 4,55 dan 4,48 dari dua validator 4,51 skala 5. Diperoleh dari validasi hasil tes hasil belajar media tutorial matlab berbasis web dapat dilihat dari Tabel 5.

Tabel 4. Hasil Validasi Respon Kuesioner Mahasiswa (Literasi Digital)

\begin{tabular}{|c|c|c|c|c|c|}
\hline \multirow{2}{*}{ Validator } & \multicolumn{4}{|c|}{ Skor Aspek } & \multirow{2}{*}{ Skor Rata-rata } \\
\hline & Bahasa & Kesesuaian & Kejelasan & Kelayakan & \\
\hline I & 4,42 & 4,56 & 4,7 & 4,50 & 4,55 \\
\hline II & 4,29 & 4,1 & 4,84 & 4,67 & 4,48 \\
\hline
\end{tabular}


DOI: https://doi.org/10.24127/ajpm.v9i3.2943

Tabel 5. Hasil Validasi Tes Hasil Belajar

\begin{tabular}{ccccc}
\hline \multirow{2}{*}{ Validator } & \multicolumn{3}{c}{ Aspek } & \multirow{2}{*}{ Skor Rata-rata } \\
\cline { 2 - 4 } & Materi & Konstruksi & Bahasa & \\
\hline I & $92 \%$ & $94,33 \%$ & $88 \%$ & $91 \%$ \\
II & $97 \%$ & $91,33 \%$ & $82 \%$ & $90 \%$ \\
\hline
\end{tabular}

Berdasarkan Tabel 5, hasil validasi dari hasil tes belajar siswa dikatakan baik oleh validator dengan mendapatkan skor masing-masing validator adalah $91 \%$ dan $90 \%$ dan jika digabungkan akan mendapat persentase gabungan sebesar $90,5 \%$ dari $100 \%$ Sehingga hasil tes dari hasil

Tabel 6. Hasil Validasi Media Tutorial Matlab pembelajaran dapat digunakan untuk mengetahui hasil efektivitas penggunaan media tutorial berbasis web. Selanjutnya, hasil validasi media tutorial matlab berbasis web yang telah dinilai oleh validator dapat dilihat dari Tabel 6.

\begin{tabular}{ccccc}
\hline Validator & $\begin{array}{c}\text { Skor } \\
\text { Empiris }\end{array}$ & $\begin{array}{c}\text { Skor } \\
\text { Harapan }\end{array}$ & $\begin{array}{c}\text { Persentase } \\
\text { Validitas }\end{array}$ & $\begin{array}{c}\text { Persentase } \\
\text { Validasi Akhir }\end{array}$ \\
\hline I & 58 & 75 & $77,33 \%$ & $79,33 \%$ \\
II & 69 & 75 & $81,33 \%$ & \\
\hline
\end{tabular}

Berdasarkan Tabel 6, diperoleh hasil analisis validasi yang menunjukkan bahwa media tutorial matlab berbasis web yang dikembangkan mendapatkan persentase validitas akhir sebesar $79,33 \%$ yang termasuk dalam kategori cukup valid.

Berdasarkan hasil uji coba terbatas di Universitas PGRI Madiun, bahwa hasil yang tercapai dari 22 mahasiswa pada aspek kepraktisan $(\mathrm{P})=$ $81,67 \%$. Adapun untuk uji coba terbatas dalam penggunaan media tutorial matlab berbasis web memperoleh skor rata-rata 80,50 sehingga dinyatakan memenuhi persentase ketuntasan. Hal ini menunjukkan bahwa media tutorial matlab berbasis web dapat dikatakan efektif.

Berdasarkan hasil uji coba lapangan dari 22 mahasiswa pada perkuliahan metode numerik, bahwa hasil yang dicapai pada aspek kepraktisan $(\mathrm{P})=84,50 \%$. Adapun untuk uji lapangan dalam menggunakan media tutorial matlab berbasis web memperoleh skor rata-rata 87,50 sehingga dinyatakan memenuhi persentase ketuntasan. Hal ini menunjukkan bahwa media tutorial matlab berbasis web dapat dikatakan sangat efektif.

Berdasarkan hasil pengambilan data yang diperoleh dari respon kuesioner mahasiswa mengenai pengambilan data kuesioner literasi digital terhadap penggunaan media tutorial matlab berbasis web melalui e-learning Universitas PGRI Madiun (eLMA), mengadaptasi kuesioner dari penelitian angket literasi digital mahasiswa yang mengacu secara umum dari 6 indikator dengan total 30 butir pertanyaan. Diperoleh capaian dari respon mahasiswa dapat pada Tabel 7 . 
DOI: https://doi.org/10.24127/ajpm.v9i3.2943

Tabel 7. Hasil Respon Literasi Digital Mahasiswa

\begin{tabular}{cccc}
\hline Indikator & Respon Mahasiswa & Capaian & Persentase Respon \\
\hline 1 & 479 & 528 & $79,83 \%$ \\
2 & 848 & 1056 & 70,67 \\
3 & 256 & 352 & 64 \\
4 & 258 & 352 & 64,5 \\
5 & 154 & 176 & 77 \\
6 & 138 & 176 & 69 \\
\hline Jumlah & 2133 & 2640 & 425 \\
\hline \multicolumn{4}{c}{ Rata-Rata Respon Literasi Digital } \\
\hline
\end{tabular}

Adapun perolehan analisis dari Tabel 7, memperoleh kondisi yang dicapai dari respon literasi digital, menunjukkan hasil persentase rata-rata respon literasi digital $70,83 \%$. Hal ini menunjukkan bahwa hasil perolehan respon tersebut yang paling cenderung dominan terlihat dari literasi digital, dengan indikator diantaranya: (1) penggunaan teknologi, (2) penggunaan smartphone dan (5) Online Safety.

$\begin{array}{ccr}\text { Media tutorial matlab } & \text { berbasis } \\ \text { web dikatakan layak } & \text { untuk }\end{array}$ dipergunakan jika terpenuhi ketiga kategori pengembangan, yaitu valid, praktis, dan efektif. Adapun penjelasan terhadap ketiga kriteria akan dipaparkan sebagai berikut.

Media tutorial dinyatakan valid apabila memperoleh skor validitas gabungan > 70\% (Akbar, 2013). Data yang diperoleh dari hasil gabungan dua validator menunjukkan sebesar 79,33\%. Hasil tersebut dinyatakan dalam kriteria yang cukup valid tetapi memperoleh beberapa saran dari validator, salah satunya media perlu menyesuaikan tampilan yang lebih sederhana dan memiliki petunjuk sederhana tanpa banyak teks. Demikian, sehingga hasil dari validasi yang diperoleh sebesar $79,33 \%$, media tutorial matlab berbasis web yang dikembangkan dapat dipergunakan sebagai alternatif media pembelajaran dalam perkuliahan metode numerik.

Media dikatakan praktis jika diperoleh skor yang memenuhi kriteria $70 \%$ yang memberikan respon positif. Menurut (Saputro, 2011) jika tanggapan direspon positif oleh peserta didik untuk setiap pernyataan di setiap aspek dan persebtase tanggapan siswa terkandung dalam setiap aspek sebesar 70\%. Hasil respon kuesioner pada saat uji coba terbatas diperoleh $(\mathrm{P})=81,67 \%$ terkategorikan tingkat kepraktisan tinggi, sedangkan pada saat uji coba lapangan diperoleh $(\mathrm{P})=84,50 \%$ terkategorikan tingkat kepraktisan tinggi. Hal tersebut didukung dari tanggapan positif dari mahasiswa bahwa mereka merasa lebih nyaman mengulangi materi secara mandiri dalam mengakses materi metode numerik, apabila ada materi yang kurang dipahami. Hal ini sejalan dengan penelitian (Lusiana \& Setyansah, 2016) yang menyatakan bahwa media tutorial dapat digunakan sebagai alternatif media pembelajaran yang menarik. Selain itu (Zhang \& Maas, 2019) menyatakan bahwa untuk meningkatkan keterampilan pemrograman khususnya perhitungan memerlukan studi simulasi yang diberikan oleh instruktur mereka agar mudah diikuti. Salah satu aspek yang penting dari MATLAB (Setyansah, 2018) adalah kemampuan untuk memvisualisasikan berbagai basis 
data, grafik dan fungsi yang kompleks untuk diselesaikan. Berpandangan dari hal tersebut dalam penelitian (Setyansah \& Apriandi, 2019) bahwa penyelesaian analisis numerik dalam penggunaan komputasi MATLAB memerlukan berupa tutorial materi. Melihat hasil penelitian ini maka menunjukkan respon yang positif dari mahasiswa bahwa pengulangan penyelesaian materi metode numerik dapat menggunkaan media tutorial matlab berbasis web.

Media dikatakan efektif menurut (Hobri, 2010) jika persentase kelengkapan individu telah mencapai $\geq 80 \%$ yang secara klasik memperoleh skor minimum 75 dari skor keseluruhan. Hal yang dikemukan oleh (Wijaya, 2011) bahwa bentuk materi, ujian, kuis dan cara-cara pendidikan lainnya dapat diimplementasikan kedalam web, seperti materi guru yang dipresentasikan di web dan dapat diunduh oleh peserta didik. Adapun untuk uji coba terbatas dalam penggunaan media tutorial matlab berbasis web memperoleh skor rata-rata 80,50 sehingga dinyatakan memenuhi persentase ketuntasan. Dari skor rata-rata uji coba terbatas terdapat dua mahasiswa yang masih mendapatkan skor di bawah 70 . Sedangkan, untuk uji lapangan dalam menggunakan media tutorial matlab berbasis web memperoleh skor rata-rata 87,50 sehingga dinyatakan memenuhi presentase ketuntasan. Dari skor ratarata uji coba terbatas terdapat tiga mahasiswa yang masih mendapatkan skor di bawah 70. Hal ini didukung (Irianti \& Wijaya, 2017) menunjukkan media E-Learning berbasis Moodle pada mata pelajaran lingkaran kelas VIII SMP berdasarkan aspek efektifitas dalam hal implementasi pembelajaran memenuhi kriteria efektif dengan persentase rata-rata $86,8 \%$, bahwa pembelajaran dengan menggunakan web memberikan dampak efektif. Dalam penelitian (Apriandi \& Setyansah, 2017) didapatkan bahwa penerapan media simulasi Matlab berbasis konseptual interaktif dalam pembelajaran dapat meningkatkan pemahaman mahasiswa tentang Sistem Persamaan Linier.

Penguatan literasi digital dalam penggunaan media tutorial Matlab berbasis Web dilihat berdasarkan capaian kondisi yang diperoleh dari kuesioner literasi digital, hasil persentase rata-rata respon literasi digital $70,83 \%$ dikategorikan cukup sebagai penguatan. Hasil perolehan respon mahasiswa dalam penguatan literasi digital tersebut yang paling cenderung dominan dari capaian indikator terlihat pada aspek diantaranya: (1) penggunaan teknologi, (2) penggunaan smartphone dan (5) Online Safety. Dampak yang terlihat dari penguatan literasi digital terlihat bahwa kecenderungan mahasiswa lebih memperhatikan keamanan digital dan penggunaan smartphone dalam kegiatan pembelajaran, maka hasil pembelajaran lebih menyesuaikan kebutuhan utama dari mahasiswa. Hal ini perlu menjadi perhatian utama bagaimana pembelajaran mudah diakses melalui smartphone.

\section{KESIMPULAN DAN SARAN}

Hasil dalam penelitian pengembangan dari media tutorial matlab berbasis web memperoleh hasil media pembelajaran yang dinayatakan layak dipergunakan dengan tingkatan kriteria validitas cukup valid yang diperoleh dari persentase rata-rata dari angket validasi media sebesar $79,33 \%$. Pada tingkatan kriteria kepraktisan, data uji coba terbatas diperoleh $(\mathrm{P})=81,67 \%$ terkategorikan tingkat kepraktisan tinggi, sedangkan pada saat uji coba 
DOI: https://doi.org/10.24127/ajpm.v9i3.2943

lapangan diperoleh $(\mathrm{P})=84,50 \%$ terkategorikan tingkat kepraktisan tinggi. Pada tingkatan kriteria efektivitas memenuhi dengan skor hasil rata-rata dalam uji coba terbatas memperoleh skor rata-rata 80,50 yang berarti dikatakan tinggi terhadap prestasi mahasiswa dalam menggunakan media tutorial matlab berbasis web. Sedangkan uji lapangan memperoleh skor rata-rata 87,50 yang berarti dikatakan tinggi. Kondisi tersebut telah membuat pencapaian penguatan literasi digital dengan menggunakan media tutorial matlab berbasis web sebesar 70,83\% terkategorikan cukup dominan terhadap aspek (1) penggunaan teknologi, (2) penggunaan smartphone dan (5) Online Safety.

Berpandangan dari kelemahan yang muncul dalam penelitian ini, diantaranya adalah batasan tutorial yang dikembangkan masih bersifat menyajikan materi dilengkapi dengan penggunaan matlab. Kami menyarankan keterlibatan dosen dan mahasiswa dalam penyelenggaraan secara daring, sehingga kegiatan pembelajaran menjadi lebih berkualitas. Disisi lain, hasil dari penguatan literasi digital cenderung dominan terhadap capaian indikator terlihat aspek pada: (1) penggunaan teknologi, (2) penggunaan smartphone dan (5) Online Safety. Maka kami menyarankan mengoptimalkan penggunaan teknologi, penggunaan smartphone dan online safety menjadi prioritas yang perlu diperhatikan ketika mempersiapkan literasi digital dalam proses pembelajaran.

\section{DAFTAR PUSTAKA}

Akbar, S. (2013). Instrumen Perangkat Pembelajaran. PT Remaja Posdakarya.
Apriandi, D., \& Setyansah, R. K. (2017). Penerapan Media Simulasi Matlab Berbasis Interactive Conceptual untuk Meningkatkan Pemahaman Konsep Mahasiswa. AKSIOMA: Jurnal Program Studi Pendidikan Matematika, 6(2), 189. https://doi.org/10.24127/ajpm.v6i2. 968

Atep, S., \& Dewi, R. (2019). Literasi digital abad 21 bagi mahasiswa PGSD : apa , mengapa , dan bagaimana. Current Research in Education: Conference Series Journal, 1(1), 1-7.

Broadbent, J., \& Poon, W. L. (2015). Self-regulated learning strategies $\&$ academic achievement in online higher education learning environments: A systematic review. Internet and Higher Education, 27, 1-13. https://doi.org/10.1016/j.iheduc.20 15.04.007

Febliza, A., \& Oktariani. (2020). Pengembangan Instrumen Literasi Digital bagi Siswa dan Guru. Jpk Unri, 5(1), 1-9.

Fernandez-Villavicencio, N. G. (2010). Helping students become literate in a digital, networking-based society: A literature review and discussion. International Information and Library Review, 42(2), 124-136. https://doi.org/10.1016/j.iilr.2010.0 4.012

Hobri. (2010). Metodologi Penelitian Pengembangan (Aplikasi pada Penelitian Pendidikan Matematika) (H. Al-Surkief (ed.); 1st ed.). Pena Salsabila. 
Irianti, N. P., \& Wijaya, E. M. S. (2017). Pengembanagn Media Pembelajaran E-Learning Berbasis Moodle Pada Pokok Bahasan Lingkaran Kelas VIII SMP. JIPM (Jurnal Ilmiah Pendidikan Matematika), 5(2), 122. https://doi.org/10.25273/jipm.v5i2. 1175

Ku, D. T., \& Chang, C. S. (2011). The effect of academic discipline and gender difference on Taiwanese college students' learning styles and strategies in web-based learning environments. Turkish Online Journal of Educational Technology, 10(3), 265-272.

List, A. (2019). Defining digital literacy development: An examination of pre-service teachers' beliefs. Computers and Education, 138(May 2018), 146-158. https://doi.org/10.1016/j.compedu. 2019.03.009

Lusiana, R., \& Setyansah, R. K. (2016). Media Tutorial Berbasis Problem Solving untuk Mengembangkan Kemandirian Belajar Mahasiswa pada Mata Kuliah Aljabar Linier. Seminar Matematika Dan Pendidikan Matematika UNY, 465-474.

Means, B., Toyama, Y., Murphy, R., Bakia, M., \& Jones, K. (2009). Evaluation of Evidence-Based Practices in Online Learning. Structure, 66.

Muchsini, B., \& Siswandari, S. (2018). Digital Natives' Behaviours and Preferences: Pre-Service Teachers Studying Accounting. International Journal of Pedagogy and Teacher Education, 2(2), 355. https://doi.org/10.20961/ijpte.v2i2.
24088

Muchsini, B., \& Siswandari, S. (2020). Class Culture and The Academic Stress of Digital Natives Generations. Jurnal Cakrawala Pendidikan, 39(1), 102-110. https://doi.org/10.21831/cp.v39i1.2 6910

Rahmah, A. (2015). Digital Literacy Learning System for Indonesian Citizen. Procedia Computer Science, 72, 94-101. https://doi.org/10.1016/j.procs.201 5.12.109

Reyna, J. (2020). Twelve Tips for COVID-19 friendly learning design in medical education. MedEdPublish, 9(1), 1-16. https://doi.org/10.15694/mep.2020. 000103.1

Saputro. (2011). Pengembangan Perangkat Pembelajaran Matematika dengan Media Visual Basic Net 2008 pada Materi Lingkaran di Kelas VIIIB MTs Negeri Krian Sidoarjo. Institut Agama Islam Negeri Sunan Ampel Surabaya Fakultas Tarbiyah Jurusan Pendidikan Matematika.

Sari, N., Wibowo, T., Kurniawan, H., Studi, P., Matematika, P., \& Purworejo, U. M. (2019). Prosiding Sendika: Vol 5 , No 1, 2019637 Prosiding Sendika: Vol 5, No 1, 2019 638. 5(1), 637-646.

Setyansah, \& Apriandi. (2019). Development of Textbook Based on E-Learning "Matlab Simulation" in Numerical Analysis. Journal of Physics: Conference Series, 1254(1), 0-6. https://doi.org/10.1088/17426596/1254/1/012024 
DOI: https://doi.org/10.24127/ajpm.v9i3.2943

Setyansah, R. K. (2018). Kalkulus Diferensial lengkap dengan tutorial MATLAB. Deepublish. https://penerbitbukudeepublish.co m/shop/buku-kalkulus-diferensial/

Wardani, D. N., Toenlioe, A. J. E., \& Wedi, A. (2018). Daya Tarik Pembelajaran Di Era 21 Dengan Blended Learning. Jurnal Kajian Teknologi Pendidikan (JKTP), 1(1), 13-18.

Waschull, S. B. (2001). The Online Delivery of Psychology Courses: Attrition, Performance, and Evaluation. Teaching of Psychology, 28(2), 143-147. https://doi.org/10.1207/S15328023 TOP2802_15

Wijaya, M. (2011). Pengembangan model pembelajaran e-learning berbasis web dengan prinsip $e$ Pedagogy dalam meningkatkan hasil belajar. Universitas Pendidikan Indonesia.

Zhang, X., \& Maas, Z. (2019). Using R as a Simulation Tool in Teaching Introductory Statistics. International Electronic Journal of Mathematics Education, 15(1), 599-610.

https://doi.org/10.29333/iejme/577 3 